\title{
Jack Mezirowin oppimisnäkemyksen soveltamisesta suomalaiseen aikuiskoulutukseen
}

Jack Mezirowin ajattelu on melko vaikeaselkoista, mutta kokonaisvaltaista ja oivaltavaa ja sellaisena kiehtovaa. Mezirowin oppimisteoriassa tarkastellaan abstraktilla tasolla aikuisten oppimisen ulottuvuuksia tai tasoja. Tarkastelun kohdentaminen, vaikkakin abstrahoiden, oppimisen prosessipiirteisiin tekee mahdolliseksi kiinnittää huomio erityisesti aikuisille tyypilliseen oppimiseen, erotukseksi tiettyjen, ennalta määriteltyjen oppisisältöjen omaksumisesta eri ikäkausina. Erottelu on tietenkin vain käsitteellinen eikä tee kysymystä opittavan sisällöstä samantekeväksi aikuisten oppimisessa, pikemminkin päinvastoin.

Tässä artikkelissa tarkastellaan Mezirowin teosta Transformative Dimensions of Adult Learning (1991), joka on tähän mennessä ainoa hänen ajattelunsa kokonaisesitys. Mezirowin aikaisemmin julkaistut artikkelit saanevat taustaa ja lisävalaistusta tästä teoksesta. Toisaalta varhempien esitysten ja teokseksi muokatun kehittelyn välillä saattaa olla katkoksia. Niihin tai muihin sen kaltaisiin ongelmiin ei tässä oteta kantaa. Tavoitteena on keskustella siitä, mitä uusia näkökulmia Mezirowin oppimiskäsitys tarjoaa aikuiskoulutukseen kenttään.

Erilaisille lukutavoille ja tulkinnoille altis teksti antautuu huonosti referointiin. Mezirowin ajatukset eivät avaudu yksittäisten tekstikohtien lukemisella. Tämän kirjoituksen tekstikohtaviittaukset ovat siten vain suuntaa antavia.

\section{Jack Mezirowin oppimiskäsityksen piirteitä}

Mezirow tarkastelee oppimista yksilön elämän vaihtuvien tilanteiden pakottamana ilmiönä. Mezirowin ajattelussa oppiminen kiinnittyy yksilöön, mutta tämä ei nähdäkseni anna aihetta pitää hänen ajatuksiaan ilmauksena individualistisesta ihmiskäsityksestä. Kysymys on pikemminkin näkökulmasta, oppimisen tarkastelusta oppijan kannalta. Yksilökeskeisyyden sijasta voisi Mezirowin ajattelua luonnehtia oppijakeskeiseksi. Kokonaisuutena Mezirowin oppimisen teoria korostaa yksilön sosiaalista ja kulttuurista riippuvuutta, myös itse oppimisen prosessissa.

Mezirowin mukaan aikuisen oppimisen lähtökohtana on kaikissa tapauksissa yksilön ei-tietoinen, alkuperäinen sosialisaatio. Tämä sosialisaatio on kulttuurisesti määräytyvä ja siinä yksilö omaksuu ympäröivän kulttuurin tavat "nähdä" maailma, antaa merkityksiä asioille ja ilmiöille. Kulttuurin merkitysjärjestelmän omaksumisessa kielellä on ratkaisevan tärkeä merkitys. Kielen merkityksen problematisoiminen oppimisen kannalta on yksi Mezirowin aikuiskasvatuksen kannalta kiinnostavista oivalluksista (Mezirow 1991,34; 18-19).

Mezirowin teoriassa oppimista aikaansaavana perimmäisenä tekijänä, motiivina, on ihmisen tarve ymmärtää omaa kokemustaan. Tarve ymmärtää omaa kokemusta on Mezirowin mukaan yksi perustavimmista inhimillisistä tarpeista. Oppimisessa on yksilön kannalta mukaan kysymys merkityksen luomisesta (making meaning) joka on luonteeltaan todellisuuden tulkintaa. Tavanomaisessa oppimisessa on kyse vanhan tai annetun tulkinnan liittämisestä uuteen asiaan (esim. luokittelu), transformatiivisessa oppimisessa tulkitaan kokemus uudesta, tiedollisesti kattavammasta perspektiivistä käsin (emt, 4-11). 
Mezirow käyttää apukäsitteinä kahta termiä, merkitysperspektiivi ja merkitysskeema. Merkitysperspektiivi edustaa kieleen ja kulttuuriin sidottua maailmankuvan tasoista tietoisuuden ulottuvuutta, joka mm. suuntaa huomiota ja valikoi kiinnostuksen kohteita myös ei-tietoisella tasolla. Käsitteellisesti siinä voidaan erottaa episteeminen, sosiolingvistinen ja psykologinen ulottuvuus. Merkitysperspektiivi määrittelee kokemuksen konstruoinnin olennaiset ehdot, tulkinnan perustavaa laatua olevat periaatteet. Merkitysskeemat edustavat eriytyneempiä tietorakenteita tai tiedon ja kokemuksen alueita, jotka jäsentävät yksilön kokonaistietämystä (vrt. ideaan kognitiivisista skeemoista). Oppimisen periaatteellisina vaihtoehtoisina lajeina tai ulottuvuuksina Mezirow erottaa neljä tapausta:

- yksilö voi oppia olemassaolevan merkitysskeeman puitteissa

- yksilö voi oppia kokonaan uuden merkitysskeeman

- yksilö voi muuttaa jo olemassaolevaa merkitysskeemaa ja

- yksilö voi muuttaa koko merkitysperspektiiviään (ernt, 93-94).

Vasta aikuisiällä mahdollinen ja siinä mielessä aikuisuudelle tyypillinen transformatiivinen oppiminen koskee erityisesti kahta viimeksimainittua. Olemassaolevien merkitysskeemojen muuttuminen luo ristiriitoja merkitysperspektiivin tasolla. Dilemma saattaa koskea myös suoraan merkitysperspektiiviä, kun skeematasot vähittäisemmän muutoksen johdosta luovat ristiriitoja maailmankuvan ja tietojen välillä.

Vaikka Mezirowin tyypittelevä esitys oppimisesta saattaa ensisilmäyksellä näyttää abstraktilta ja kaavamaiselta, se jäsentää juuri aikuisiälle leimallisia oppimisprosesseja. Traditionaalisesti on aikuistenkin oppimisen ajateltu olevan koulutuslähtöistä. Tietyssä triviaalissa mielessä tämä tietenkin pitää paikkansa, esim. koulutustason vaikutuksena. Kuitenkin tiukassa näyttää istuvan käytännössä ajatus siitä, että oppiminen on ensisijaisesti koulutuksen tai opetuksen funktio, vaikka tämä sopii huonosti yhteen kaiken sen kanssa, mitä koulutuskeskustelussa on tuotu esille elinikäisen oppimisen periaatteista, itseohjautuvuudesta, reflektiivisyydesta jne.

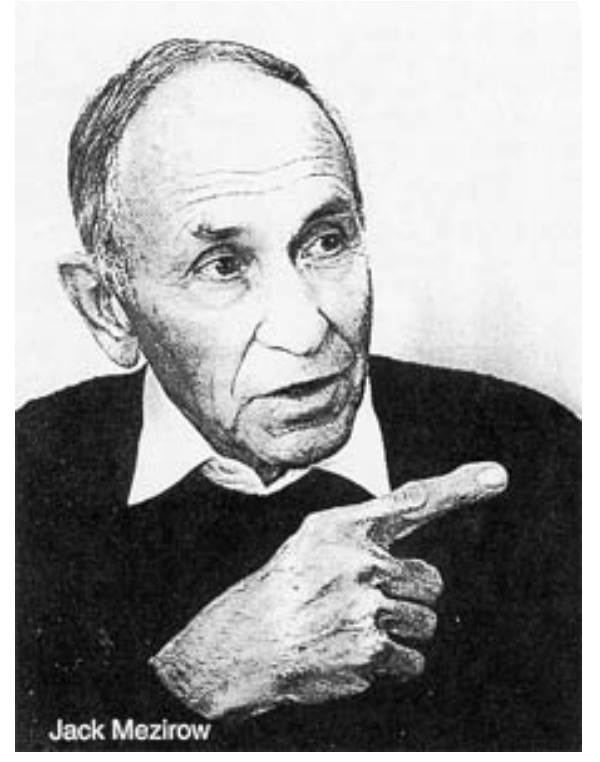

Mezirowin oppimiskäsitys yhdistää kiinnostavalla tavalla oppimisen ja kehityksen. juuri määrittelemällä oman kokemuksen ymmärtämisen oppimisen perimmäiseksi motiiviksi aikuisilla, transformatiivinen oppiminen liittää yhteen oppimisen ja toiminnan, "elävän elämän" ja oppimisen. Mezirow on kritisoinut aikuiskoulutusta siitä, ettei yksilön kokemusta ja henkilökohtaista viitekehystä oteta riittävästi huomioon. Koulutuslähtöinen oppimisnäkemys onkin pitkälle laiminlyönyt kokemuksen käsitteellisen erittelyn. Tämä lienee saanut aikaan sen, että työkokemuksia, koulutuskokemuksia, lukukokemuksia, mediakokemuksia jne. on käsitelty irrallisina kategorioina elämänkokemuksessa. Periaatteessa on kuitenkin mahdotonta edes kuvitella oppimista yksilön kokemuspiirin ulkopuolella.

Transformatiivinen oppiminen liittyy yksilön kehitykseen. Sen päämäärän Mezirow määrittelee avoimena: tämänkaltaisen oppimisen tavoitteena on saavuttaa entistä kattavampi, erottelukykyisempi, joustavampi (permeable) ja integroivampi merkitysperspektiivi (emt, 155). Aikaisempaa parempi, merkityksin jäsentynyt perspektiivi on transformatiivisen oppimisen tulos. Mezirowin tapa määritellä oppimisen päämäärä on merkillepantava: hän jättää tavoitteiden empiirisen määrittelyn oppijoitten ja kouluttajien konkreettiseksi tehtäväksi. Lähtökohtaisesti kulttuuriin sidotun oppimis- ja kehitysprosessin yksityiskohtainen määrittely yhdestä kulttuurista käsin olisikin epäloogista: Mezirow hahmottaa elävää prosessia, jota on mahdoton etukäteen pakottaa mihinkään yksityiskohtaisiin kaavoihin. Toisaalta Mezirow käytännön kouluttajana antaa 
kiinnostuneille kokonaisen teoksen koeteltuja menetelmiä ja tekniikoita, joiden avulla transformatiivista oppimista voi edistää erilaisissa aikuiskoulutuksen käytännöissä (Mezirow 1990).

Koska merkitysperspektiivin muuttaminen ei ole pelkästään tiedollista tasoa koskeva, vaan käsittää myös eettiset ja esteettiset kriteerit, idealisoitiin itsekäsityksen, tunteet jne., transformatiivinen oppimisprosessi ei ole kivuton ja sen kestoa on vaikea ennustaa etukäteen (Mezirow 1991, 44). Transformatiivista oppimista käynnistävä dilemma voi ilmeisesti syntyä myös koulutuksen tuloksena, vaikka Mezirow usein korostaa syviä elämänmuutoksia oppimistarvetta virittävänä tekijänä. Toisaalta myös koulutus voi olla tranformatiivista oppimista edistävää, mikä tosin ei ole lainkaan itsestäänselvää.

\section{Kriittinen reflektio transformatiivisen oppimisen edellytyksenä}

Jügen Habermasin ajattelun pohjalta Mezirow on kehitellyt erityistä aikuisuuteen sopivaa kommunikatiivisen oppimisen muotoa. Erotukseksi instrumentaalisesta, ympäristön tai toisten ihmisten manipulointiin tähtäävästä oppimisesta, kommunikatiivisen oppimisen tavoitteena on erilaisten intentioiden ymmärtäminen. Sen kohteena ovat kulttuurisesti määräytyneet käsitykset, uskomukset, tavat, normit ja roolit sekä yksilön suhde niihin. Kommunikatiivisen oppimisen tuloksena olevan tiedon validiteetin määrää syntyvä yhteisymmärrys, joka koskee joko lopputulosta tai, mikä useimmissa kysymyksissä on yhtä tärkeätä, itse kysymyksenasettelua. Kommunikatiivinen oppiminen tähtää siis aikaisempaa laajempaan ja syvempään käsitykseen asiasta.

Kommunikaation Sisäänrakennettuna tavoitteena on (yhteis)ymmärryksen saavuttaminen. Tämä koskee periaatteessa kaikkea inhimillistä kommunikaatiota. Kommunikaatio käsittää aina merkityksen arviointia laajalla alueella. Yksilön on jatkuvasti päätettävä, mitä hän pitää hyvänä, oikeana, kauniina, sopivana jne. Kommunikatiivisessa oppimisessa arvioiden asianmukaisuuden testaaminen tapahtuu pääasiassa keskustelun avulla. Keskustelun pedagogisena menetelmänä Mezirow kehittelee Habermasin ideoita rationaalisesta keskustelusta.

Rationaalisessa keskustelussa arvioihin päädytään päättelyn ja argumentaation tietä. Arvioiden paikkansapitävyyttä testataan identifioimaila ja arvioimalla argumenttien rakennetta. Rationaalisen keskustelun etuna on se, että siinä voidaan etääntyä kietoutuneisuudesta jokapäiväisen elämän konteksteihin, ihmissuhteisiin ja totunnaisiin ratkaisuihin. Rationaalisen keskustelun edellytyksenä on osanottajien tasa-arvoinen osallistuminen. On välttämätöntä, että kaikki osallistujat saavat tarkkaa ja täydellistä tietoa kosketeltavasta asiasta, että osanottajat ovat valmiita punnitsemaan keskustelussa esitettyjä argumentteja ja että osanottajat ovat valmiita hyväksymään syntyvän lopputuloksen. Osanottajilla on oltava sekä tasavertainen mahdollisuus osallistua, kyseenalaistaa, vastustaa ja arvioida esitettyjä kantoja että myös vastaava velvollisuus muita kohtaan. jotta tämä onnistuisi, on keskustelulle luotava standardit, joita osanottajat sitoutuvat noudattamaan. Olennaista on, että nämä periaatteet tehdään eksplisiittisiksi.

Rationaalisen keskustelun epäonnistuminen johtaa muiden keinojen käyttöön, traditioon tai auktoriteettiin turvautumiseen tai Puhtaaseen voiman käyttöön (emt, 75-86).

Rationaalisen keskustelun voidaan ajatella olevan kommunikatiivisen oppimisen menetelmä, jonka avulla on mahdollista edistää reflektiivistä ajattelua. Mezirow erottaa reflektion kaksi aluetta (Habermasista poiketen): reflektio on arviointia., joka kohdistuu käsiteltävän asian sisältöön ja käsittelyproseduuriin. Kriittinen reflektio puolestaan kohdistuu esitettyjen argumenttien lähtökohtiin ja taustaoletuksiin. Kriittinen reflektio tarkoittaa Mezirowilla eri vaihtoehtojen julkilausumattomien premissien tutkimista (emt, 87-89). Siten kriittinen reflektio toimii siltana yksilötason ja ei-tietoisen kulttuurin tason välillä.

Kriittinen reflektio on transformatiivisen oppimisen edellytys. Rationaalinen keskustelu edustaa kriittistä reflektiota edistävää pedagogista kommunikatiivisen oppimisen sovellutusta. Mezirowin oppimiskäsityksen 
mukaisesti kriittisen reflektion tasoa eri asioiden yhteydessä ei voi saavuttaa individualistisin menetelmin. Tietenkin pedagoginen reflektion edistäminen on yksilön kannalta vain yksi mahdollisuus. Rationaalista keskustelua käydään todennäköisesti ystävien ja ammattilaisten kesken, erilaisissa epävirallisissa verkostoissa jne. On ajateltavissa, että omaa ajattelua ja omaa kulttuuria suhteellistava oppimiskokemus on omiaan käynnistämään prosessin, joka laajentaa reflektiivistä asennetta muuhunkin toimintaan. Vastaavasti oivallus kulttuurin taustaoletusten olemassaolosta ilmeisesti voi tuottaa omiin ajatuksiin kohdistuvan kriittisen reflektion tarpeen.

Mezirow ei Habermasin tapaan korosta kriittistä itsereflektiota, vaan kulttuurin piilo-oletusten tutkimista. Kysymyksessä lienee kuitenkin ns. muna vai kana -ongelma: toinen johtaa toiseen prosessin kulussa. Joka tapauksessa transformaatiossa on kysymys laadullisesta kehitysaskeleesta, ei pelkästään passiivisesta sopeutumisesta.

Tranformaatio ei ole pelkästään tiedollinen prosessi, vaan siinä yksilö tulee tietoiseksi olettamuksista, jotka koskevat sekä havaitsemista, ymmärtämistä että tuntemista. Mezirow kuvaa oman kouluttajakokemuksensa perusteella luonnosmaisesti muutamia prosessin kriittisiä vaiheita. Transformatiivisen oppimisen prosessi alkaa pakottavalla disorientoivalla ongelmalla, johon liittyy voimakkaita tunteita sisältävä itsetutkiskelu. Oppijan aikaisemmat käsitykset eivät riitä ongelman ratkaisuun. Seuraavana vaiheena on yksilön joko episteemisen, sosiolingvistisen tai psykologisen tason oletusten kriittinen tutkiskelu ja arviointi, johon liittyy sen havaitseminen, että monet muut ihmiset ovat kokeneet samanlaisia muutoksia. Tämän jälkeen prosessi etenee tutkimalla uusien ratkaisujen, roolien, suhteiden tai toimien vaihtoehtoja. Tätä seuraa uusi orientoituminen, johon kuuluu myös uusien taitojen tai tiedollisten välineitten hankkiminen. Seuraavana vaiheena on kompetenssin hankkiminen löydetyillä uusilla alueilla. Lopulta uusi toimintamalli integroidaan osaksi elämää uuden perspektiivin sanelemien ehtojen pohjalta (emt, 169).

Kriittisiä vaiheita prosessin etenemisessä on havaittu olevan erityisesti kahdessa prosessin pisteessä. Toinen niistä on prosessin alussa, jossa oppijalla herää kriittisyys omia ideoitaan, arvojaan, elämänjärjestystään tai tunteitaan kohtaan. Toinen kriittinen vaihe on silloin, kun sitoutumisen toimintaan pitäisi seurata oivallusta, mutta tämä vaihtoehto tuntuu liian uhkaavalta tai vaativalta. Pelkkä intellektuaalisen tason tiedostaminen ei riitä, vaan tarvitaan tahtoa ja voimaa siirtyä eteenpäin (emt, 171).

Rationaalista keskustelua estäviksi tekijöiksi, vastoin tavanomaista ennakkokäsitystä, Mezirow on oman kokemuksensa nojalla havainnut keskusteluryhmän orgaanisuuden (vastakohtana sopimuksenvaraiset ryhmät) sekä sen, että ryhmän jäsenet samaistuvat ryhmään (emt, 191).

\section{Mezkowin oppimisnäkemyksen soveltamismahdollisuuksista}

Aikuiskoulutuksen kannalta oppimisen tasojen mezirowilainen käsitteellinen erottelu näyttäisi hedelmälliseltä. Oppijakeskeisessä lähestymistavassa, varsinkin elinikäisen oppimisen viitekehyksessä, on ensisijaisen tärkeää pyrkiä hahmottamaan, minkä tyyppisestä oppimisesta oppijan kannalta on kysymys. Oppimisen prosessin etenemisen ja jatkumisen kannalta on hahmotettava se, onko kyseessä oppijan kannalta kokonaan uuden merkitysskeeman luomisesta, vai jo olemassaolevan skeeman "parantelusta", syventämisestä jne. jos kyseessä on jo olemassaolevan skeeman muuttaminen kokonaan toiseksi (esimerkiksi yliopistoaineiden opiskelussa vanhentuneen paradigman korvaaminen uudella), eteen tulevat pulmat ovat oppijan kannalta todennäköisesti aivan toisennäköisiä kuin oppijalle täysin uuden tietorakenteen omaksumisessa. Aikuisten kohdalla kysymys merkitysperspektiivin muuttamisesta saattaa olla käsillä kaikissa edellisissä tapauksissa. Kouluttajien pulmana on tietysti myös se, että koulutettavien ryhmässä on erilaisessa tilanteessa olevia oppijoita. Opetuksen rakentaminen yhden oletuksen varaan kuitenkin riistää osalta oppijoita mahdollisuuden tehokkaaseen oppimiseen. 
Myös Mezirowin ajatukselle rationaalisen keskustelun pedagogisesta soveltamisesta tuntuisi olevan sosiaalista tilausta tämän hetken aikuiskoulutuksen kentässä, sen eri tasoilla. Kommunikaatio ylipäätänsä ei ole suomalaisten vahvuuslaji, eikä malleja rationaaliselle, argumentoivalle keskustelulle ole helppo löytää sen enempää julkisen tiedonvälityksen kuin erilaisten organisaatioidenkaan käytännöistä. Reflektiivisyyden lisäämisestä sekä opiskelun yhteydessä että työelämän ammattikäytännöissä on keskusteltu paljon viime vuosina. Kriittiseen reflektioon, toiminnan taustaoletusten ymmärtämiseen ja selventämiseen tähtäävä keskustelu sopii nähdäkseni sekä "välineellisen" tiedonhankinnan menetelmäksi että erilaisiin ongelmakeskeisiin lähestymistapoihin. Keskustelu tiedonhankinnan välineenä ja omien ajatusten validiteetin testauksena on suomalaisessa kulttuurissa melko vieras ajatus, vaikka sivistyneet eliitit ovat sitä harjoittaneet kautta aikojen. Toisaalta itseohjautuvuuden periaate siirtää painopistettä oppimisprosessin ulkoisesta kontrolloimisesta oppijan omatoimisen hallinnan kehittämiseen.

Keskustelumenetelmä on erityisen mielenkiintoinen erilaisten monitieteisten tai tieteidenvälisten hankkeiden yhteydessä, olipa niiden tavoite käytännöllinen tai teoreettinen. Tämän hetken polttavimmat suomalaisen yhteiskunnan haasteet, kansainvälisten yhteyksien lisääntyminen, työkulttuurin muutos sekä avoimella että julkisella sektorilla, ympäristökysymysten huomioonottamisen liittäminen osaksi normaalia päätöksentekoa sekä työttömyyteen liittyvien ongelmien ratkaisu edellyttävät vaativien ongelmanratkaisuprosessien oppimista, joissa yhden tiedonalan tietämys ei riitä. Kun varsinainen tehtävä on ongelman hahmottaminen ja tavoitteiden määrittely, keskustelun epäonnistuminen eri tiedon- ja ammattialoja edustavien saattaa muodostua kynnyskysymykseksi ongelmanratkaisussa. Erityisesti kulttuuristen piilo-oletusten tiedostaminen ja hahmottaminen konkreettisella tasolla on välttämätöntä kysymyksissä, jotka (aidosti) käsittävät arvoristiriitoja, joko kulttuurin sisäisiä tai kulttuurien välisiä. Toisaalta koulutustason kohoaminen on luonut valmiuksia ja kiinnostusta kouluttautujien keskuudessa laajentaa osaamistaan yli ammatillisten määrittelyjen rajojen. Toisaalta keskustelun harjoittaminen ei vaadi mitään mittavia investointeja, aikaa tosin kuluu jonkin verran enemmän kuin muissa opetusmuodoissa.

Kriittisen reflektion edistäminen, keskusteluna tai muuten, asettaa uusia haasteita kouluttajan ammattitaidolle. Oppijan prosessin tukeminen ja edistäminen ilmeisesti edellyttää kouluttajalta hänen oman kokemuksensa melko pitkälle vietyä reflektiota. Kouluttajan ammattitaitoon kuuluisi vähintään tunnistaa, minkä tyyppisistä ongelmista oppijan kohdalla on kulloinkin kyse. Kun nykyään iskulauseena oppijoita kehotetaan muuttumaan objektista oppimisen subjektiksi, on tarkasteltava huolellisesti myös sitä, antaako oppimistilanne myöten tällaisille prosesseille. Oletettavasti suomalainen koulutusilmapiiri on vielä melko jäykkä eikä riittävästi kykene tunnistamaan oppijoiden tarpeita. Vaikka keskustelumenetelmä vaatii osanottajilta sitoutumista ja itsekuria, siihen voi harjaantua, ja tämän jälkeen sitä voi käyttää myös "kevyenä sovelluksena" yhdistettynä muihin opetusmuotoihin. Etuna on, että kouluttaja saa koko ajan informaatiota, jonka nojalla hän voi kohdentaa omat toimenpiteensä prosessin kannalta olennaisiin asioihin.

Mezirow korostaa mm. kielen merkityksen tiedostamista oppimisessa. Kommunikatiivisen oppimisen yhtenä esteenä saattaa olla kielen luonteeseen liittyvät epäselvyydet. Kielen ambivalenttisen luonteen huomioon ottaminen esim. käsitteellisen ajattelun opettamisessa näyttää olevan melko kirjavaa. Ongelma nousee esiin juuri monitieteisten probleemien tarkastelussa. Näyttää siltä, että helposti jymähdetään käsite-erimielisyyksiin, joiden pidemmälle viety pohdinta paljastaisi näkökulmaeron ja veisi ongelman määrittelyä eteenpäin. Kouluttajalta kommunikatiivisen oppimisen kehittäminen vaatii paitsi tilannetajua myös jatkuvaa oman tietoperustansa ja asenteittensa kyseenalaistamista. Toisaalta mezirowilaiset näkökulmat oppimiseen tarjoavat kouluttajalle merkittävän ymmärtämisen projektin ja oman ammatillisen ja sen ylittävänkin kehittymisen mahdollisuuden. 